\title{
Review of Survey activities 2013
}

Edited by

Ole Bennike, Adam A. Garde and W. Stuart Watt 


\section{Geological Survey of Denmark and Greenland Bulletin 31}

\section{Keywords}

Geological Survey of Denmark and Greenland, survey organisations, current research, Denmark, Greenland.

\section{Cover photographs from left to right}

1. A Hercules aircraft from the US Air Force on the Greenland ice sheet. Photograph: Dirk van As.

2. Perhaps a future geologist searching for fossils in the Faxe quarry. Photograph: Ole Bennike.

3. In 2013 GEUS celebrated its 125th anniversary. Photograph: Jakob Lautrup.

4. Learning about geothermal energy by testing the temperature of the water. Photograph: Jakob Lautrup

\section{Frontispiece: facing page}

In 2012 and 2013 GEUS carried out field work in North Greenland (see paper by Bojesen-Koefoed et al. in this issue). The overturned sedimentary rocks exposed along the margin of the glacier belong to a Cretaceous succession in the Harder Fjord fault zone, Wandel Sea basin, northern Peary Land. Photograph: Jørgen A. Bojesen-Koefoed.

Chief editor of this series: Adam A. Garde

Editorial board of this series: John A. Korstgård, Department of Geoscience, Aarhus University; Minik Rosing, Geological Museum, University

of Copenhagen; Finn Surlyk, Department of Geosciences and Natural Resource Management, University of Copenhagen

Scientific editors: Ole Bennike, Adam A. Garde and W. Stuart Watt

Editorial secretary: Jane Holst

Referees (numbers refer to first page of reviewed article): Meri-Liisa Airo, FI (63; Morten Ahlborn, NO (23); Jens Asger Andersen, DK (47);

Kresten Anderskouv, DK (23); Anonymous (83, 91); Niels Balling, DK (75), Thue Sylvester Bording, DK (55); Synnøve Elvevold, NO (95);

Ida Fabricius, DK (27, 55); Ola Fredin, NO (39); Høgni Kalsø Hansen, DK (95); Jens Havskov, NO (75); Claus Heilmann-Clausen, DK

(35); Björn Heincke, DE (63); Mads Huuse, GB (43); Christine Hvidberg, DK (87); Simon Toft Ingvertsen, DK (47); Chris King, GB

(31); John Korstgård, DK (15, 67); Cees Laban, NL (43); Michael Larsen, DK (59); Poul-Henrik Larsen, DK (59); Sebastian H. Mernild,

CL (87); Alex Mitlehner, GB (35); Steffen B. Olsen, DK (51); Veli-Pekka Salonen, FI (39); Niels Schrøder, DK (15); Nigel Smith, GB (19);

Inga Sørensen, DK (51); Leigh Stearns, GB (79); Lars Stemmerik, DK (71); Henrik Stendal, Gl (67); Svend Stouge, DK (19); Vural Sander

Suicmez, DK (27); David Sutherland, USA (79); Nicolas Thibault, DK (31); Thomas Ulrich, DK (71); Frans Stephan van Buchem, DK (23);

Jacob Clement Yde, NO $(83,91)$.

Illustrations: Benny M. Schark, Jette Halskov, Willy L. Weng, Frants v. Platen-Hallermund and Christian Brogaard Pedersen

Layout and graphic production: Kristian A. Rasmussen

Printer: Rosendahls-Schultz Grafisk A/S, Albertslund, Denmark

Manuscripts received: 17 January 2014 - 28 March 2014

Final versions approved: 26 February 2014 - 9 May 2014

Printed: 25 June 2014

ISSN 1603-9769 (Review of Survey activities)

ISSN 1604-8156 (Geological Survey of Denmark and Greenland Bulletin)

ISBN 978-87-7871-383-4

\section{Citation of the name of this series}

It is recommended that the name of this series is cited in full, viz. Geological Survey of Denmark and Greenland Bulletin. If abbreviation of this volume is necessary, the following form is suggested: Geol. Surv. Den. Green. Bull. 31, 98 pp.

\section{Available from}

Geological Survey of Denmark and Greenland (GEUS)

Øster Voldgade 10, DK-1350 Copenhagen K, Denmark

Phone: +4538 1420 00, fax: +45381420 50, e-mail:geus@geus.dk

and at www.geus.dk/publications/bull 

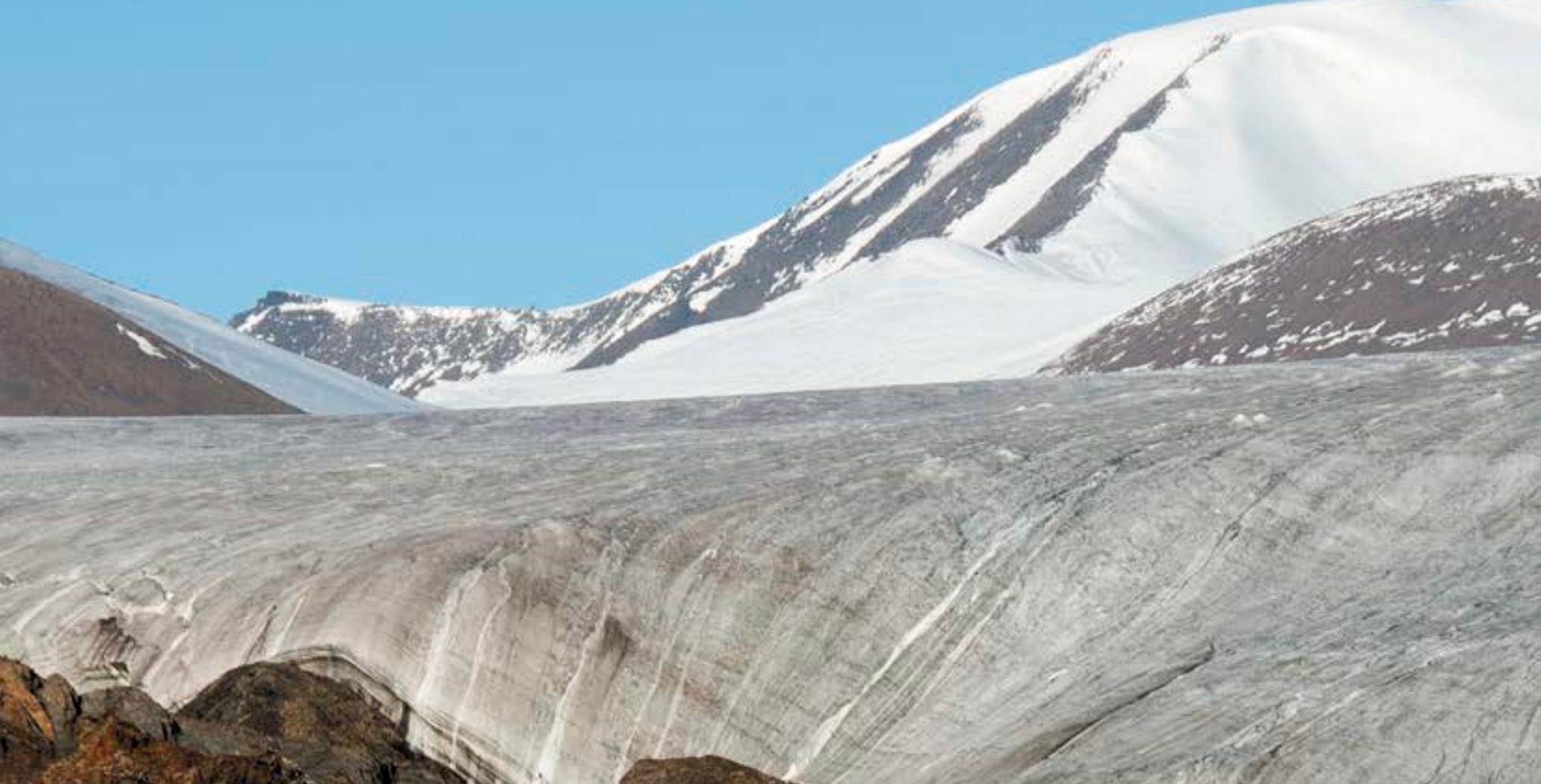

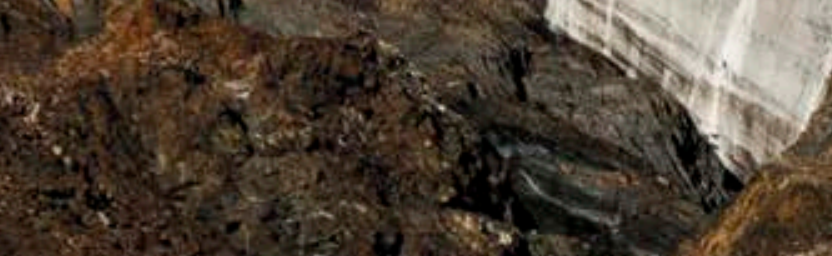

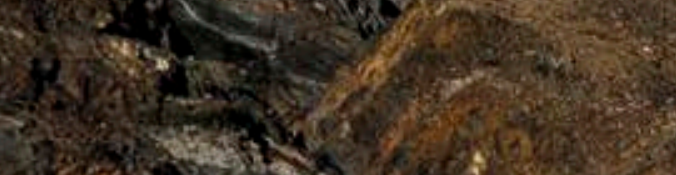

H.

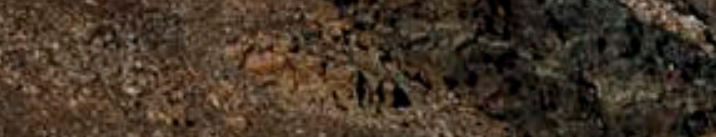

$$
+x^{2}
$$

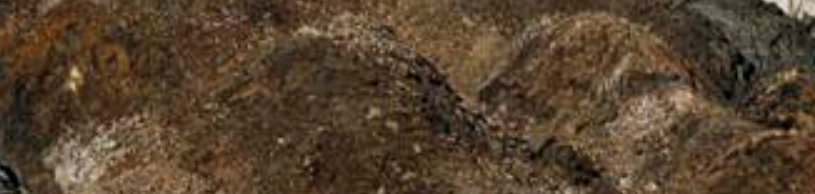

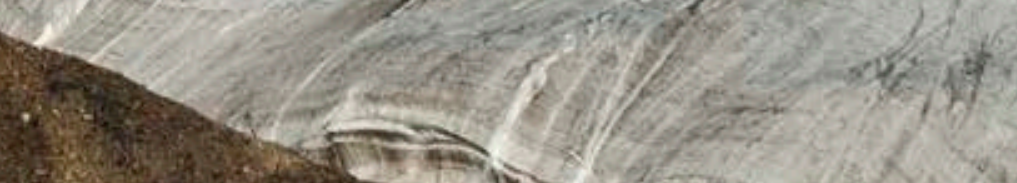

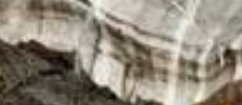

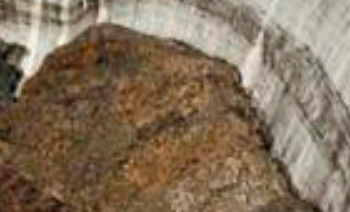

(1)

Y.7.2.

4his

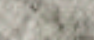
8. If Fin:

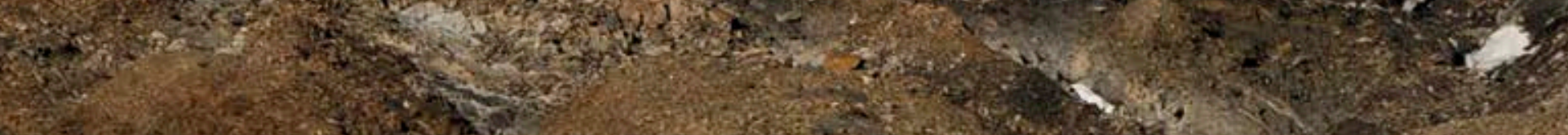




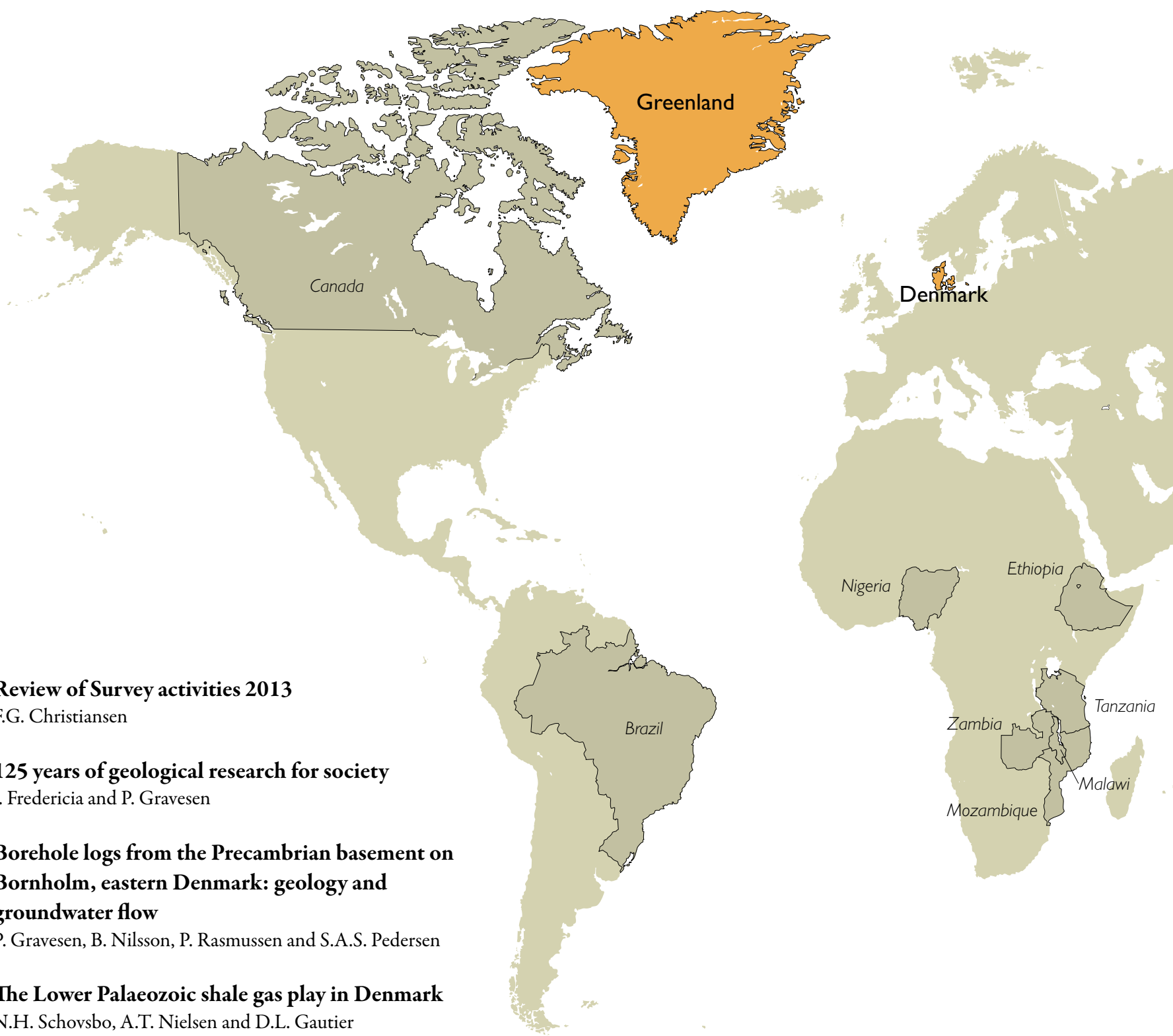

23 Seismic stratigraphy and sedimentary architecture of the Chalk Group in south-west Denmark

C. Larsen, J. Ineson and L.O. Boldreel

39 Ribbed moraines formed during the retreat of the Scandinavian ice sheet from eastern Himmerland, NE Jylland, Denmark

H. Lerche, P.tR. Jakobsen and S.A.S. Pedersen

27 A novel technique for obtaining representative water samples during $\mathrm{CO}_{2}$ core-flooding experiments on chalk at reservoir conditions

C. Kjøller and J. Zuta

43 Arctic plant remains of Weichselian age from the Danish North Sea

O. Bennike, J.O. Leth, J.B. Jensen, N. Nørgaard-Pedersen and S. Lomholt

31 Calcareous nannofossil and foraminifer biostratigraphy of the Campanian-Maastrichtian chalk of the Femern Bælt (Denmark-Germany)

E. Sheldon, C. Morigi and S.D. Møller

35 Palynological and microfossil biostratigraphy and palaeoecology over the Paleocene-Eocene transition, Femern Bælt, northern Germany

P.A. Richardt and E. Sheldon

47 Stormwater management: methods for measuring near-surface infiltration capacity in clayey till B. Bockhorn, M.B. Jensen and K.E.S. Klint

51 A multidisciplinary study of a geothermal reservoir below Thisted, Denmark M.L. Hjuler, H. Vosgerau, C.M. Nielsen, P. Frykman, L. Kristensen, A. Mathiesen, T. Bidstrup and L.H. Nielsen 
GEUS working areas 2013 shown in grey.

Orange areas are covered in this volume.

71 Integrating 3D photogeology with aeromagnetic data as a tool for base-metal exploration in East Greenland

A. Brethes, P. Guarnieri and T.M. Rasmussen

75 Earthquake swarms in Greenland

T.B. Larsen, P.H. Voss, T. Dahl-Jensen and H.P. Rasmussen

79 Outlet glacier dynamics and bathymetry at Upernavik Isstrøm and Upernavik Isfjord, NorthWest Greenland

C.S. Andresen, K.K. Kjeldsen, B. Harden, N. NørgaardPedersen and K.H. Kjær

83 Katabatic winds and piteraq storms: observations from the Greenland ice sheet

55 Estimating thermal conductivity from lithological descriptions - a new web-based tool for planning of ground-source heating and cooling

C. Ditlefsen, I. Sørensen, M. Slott and M. Hansen

59 Six years of petroleum geological activities in NorthEast Greenland (2008-2013): projects and a view of the future

J.A. Bojesen-Koefoed, P. Alsen and F.G. Christiansen

63 Aeromagnetic survey in south-eastern Greenland: project Aeromag 2013

P. Riisager and T.M. Rasmussen

67 Combining exploration and multivariate techniques to detect the Bjørnesund West gold occurrence, southern West Greenland

D.M. Schlatter and B. Møller Stensgaard

D. van As, R.S. Fausto, K. Steffen and the PROMICE project team

87 Mass loss from an ice-sheet drainage basin in West Greenland

M.L. Andersen, S.B. Andersen, L. Stenseng, H. Skourup,

W. Colgan, S.S. Kristensen, J.P.M. Boncori, A.P. Ahlstrøm,

X. Fettweiss, R. Forsberg, M. Citterio, J.E. Box, D. van As and

R.S. Fausto

91 Surface albedo as a proxy for the mass balance of Greenland's terrestrial ice

W. Colgan, J.E. Box, R.S. Fausto, D. van As, V.R. Barletta and R. Forsberg

95 To what extent is Denmark vulnerable to mineral supply shortage?

P. Kalvig, R.J. Clausen, N. Fold and K. Hanghøj 



\title{
Review of Survey activities 2013
}

\author{
Flemming G. Christiansen \\ Deputy Director
}

2013 was a very special year for the Geological Survey of Denmark and Greenland (GEUS), which acquired its present name in 1995 when the Geological Survey of Denmark, established in 1888, and the younger Geological Survey of Greenland were merged. On 4 April 2013 GEUS celebrated its 125 th anniversary with a series of presentations by prominent guests and GEUS scientists followed by a reception and a gala evening. GEUS' 125-year long history has provided an overwhelming body of results and experience, and today GEUS is broader, stronger and more international and collaborative than ever, covering all aspects of which a geological survey can be of use for society.

The anniversary is also reflected in this issue of Review of Survey activities that contains a total of 22 four-page papers, 11 on Denmark, nine on Greenland and three on broader themes: $\mathrm{CO}_{2}$ capture and storage, the recently established Center for Minerals and Materials (MiMa) housed within the Survey - and, of course, a paper dedicated to the 125th anniversary.

This first paper highlights the anniversary and introduces the newly published book on the history of GEUS 'We the people down to earth' (in Danish: Vi de jordbundne); a book that gives glimpses and highlights of the story of GEUS spiced with anecdotes on colourful characters, culture and politics.

\section{Activities in Denmark}

The activities and research in Denmark by GEUS cover many topics within our main programme areas: data, water, energy, mineral resources as well as nature and climate.

The island of Bornholm has a different geological history from the rest of Denmark; a dominance of outcropping basement rocks and Palaeozoic sedimentary rocks gives special challenges and possibilities. One paper describes the use of geophysical wire-line borehole logs from the Precambrian basement and the mapping of fracture patterns affecting groundwater flow.

Previous coring results from Bornholm have provided important geological input for assessing the unconventional gas resources in the Lower Palaeozoic shales of Denmark. Based on several years of collaboration with GEUS, the U.S. Geological Survey presented their shale gas estimate in Novem- ber 2013 suggesting that significant technically recoverable resources may be present in several prospective areas.

Chalk is a very important rock for Denmark as it hosts more than $90 \%$ of the Danish petroleum reserves in the North Sea but it also has many other important uses. One paper is from a pilot project in south-west Denmark where seismic stratigraphy and sedimentary architecture of the chalk group has been used in a geothermal evaluation. Another paper describes a new technique for important $\mathrm{CO}_{2}$ flooding experiments of chalk at reservoir conditions; if these experiments can be up-scaled, their results are potentially crucial to enhanced oil recovery.

Large infrastructure projects such as tunnels and bridges require detailed geotechnical knowledge of the subsurface, and based on material from new core holes, a more detailed understanding of understudied stratigraphic intervals may be reached. Based on cores from the Femern Bælt, one paper describes a study of the calcareous microfossil and foraminiferal biostratigraphy of the Campanian-Maastricthian chalk, and another paper focuses on the palynological and microfossil biostratigraphy and palaeoecology of the PaleoceneEocene transition.

GEUS is involved in many studies of Quaternary and recent geological processes. One paper describes ribbed moraines from eastern Himmerland in Jylland formed during the retreat of the Scandinavian ice sheet. Another paper focuses on plant remains from cores in the North Sea, and demonstrates that parts of this area constituted an open, treeless, tundra-like environment in the Weichselian. A third paper is on stormwater management, where a test site in Høje Taastrup has been used to evaluate the infiltration capacity of clayey till. Based on field experiments, the paper discusses how different methods can be used to measure the infiltration capacity of the sediments.

Geothermal energy and ground-source heating may be of great importance in many areas in Denmark in order to live up to the ambition that by 2050 energy and transport shall be $100 \%$ based on renewable energy. Over many years, GEUS has been involved in an increasing number of projects covering different aspects of geothermal energy and groundsource heating. One paper describes a multidisciplinary approach to geothermal reservoir characterisation in Thisted, 
where Denmark's first plant was established already in 1984. The plant now needs to increase its capacity with a new borehole. Another paper goes into detail about one of the critical key parameters - thermal conductivity of soils.

\section{Activities in Greenland}

Once again there was a high level of field activities in Greenland in 2013 with large field programmes in North Greenland and in the Gardar Province in South Greenland. Many other field studies were also carried out. Results from these large and small projects that are very important for evaluating and marketing the resource potential in Greenland and for monitoring climate changes will be presented in the coming years.

In this issue, results are presented from other completed and on-going projects. A first paper gives a review of six years of petroleum geological activities in North-East Greenland with focus on completed projects, and takes a look at the future. The activities were carried out prior to the preparation of recently completed offshore licensing rounds, and the studies are very important for evaluating key geological risks such as occurrence and quality of petroleum source rocks, understanding critical reservoir intervals and the uplift history. They are therefore crucial for planning of future exploration activities by both the authorities and industry.

Several papers focus on mapping and evaluation of the mineral potential in Greenland. One paper gives details of an aeromagnetic survey that was carried out in southern East Greenland in 2013, a region where GEUS has been active over several years with large completed and planned field programmes. The paper outlines how data can be applied to map regional geological and tectonic features. The project Aeromag 2013 has recently been released by the Greenland authorities. Another paper describes how exploration and multivariate techniques were used to detect a gold occurrence in southern West Greenland. A third paper demonstrates how integration of $3 \mathrm{D}$ photogeology, aeromagnetic and other geophysical data can be used as a promising tool for base-metal exploration in the remote region of East Greenland.
Earthquake swarms in Greenland are a very interesting subject that can now be analysed in greater detail than previously thanks to an increased number of seismic stations. Data from older detected swarms have been revisited and two new earthquake swarms have been identified on Disko and off South-East Greenland.

Shrinking of the ice sheet and local glaciers in Greenland provide a significant contribution to global sea-level rise. Understanding the dynamics and calculation of mass loss requires a detailed understanding of climate, glacier configuration and fjord bathymetry. One paper describes a case study from the Upernavik Isstrøm and Upernavik Isfjord in North-West Greenland.

The important monitoring programme of the Greenland Ice Sheet (PROMICE) that was initiated in 2007 continuously supplies crucial data that are used in a number of subsequent projects and in key publications. Three papers in this issue use such data from PROMICE. One is on katabatic winds and explanation of piteraq storms and is based on observations from the Greenland ice sheet. A second is on mass loss on a basinal scale with its focus on a large area in West Greenland. A third paper discusses the possibility of using surface albedo as a proxy for Greenland ice mass balance. This is particularly important at the moment to help fill data gaps in gravimetric data from satellites.

\section{Broader international activities}

Internationally GEUS works in many different countries with a variety of projects and is also involved in broader thematic studies. The last paper addresses scarcity of mineral raw materials, a theme that has recently been placed high on the political agenda in the US, EU, including in Denmark, as well as in Asia. As a consequence of this, GEUS has established the Center for Minerals and Materials (MiMa) in order to identify and study important raw material chains from source to use. One of the first tasks of MiMa is to enhance our knowledge of the risk of resource scarcity and the ensuing vulnerability of Danish society. 